Global Journal of Management and Business Studies.

ISSN 2248-9878 Volume 10, Number 1 (2020), pp. 1-7

(C) Research India Publications

https://dx.doi.org/10.37622/GJMBS/10.1.2020.1-7

\title{
Bilateral Trade Relations Between India and UAE - Historical Perspective
}

\author{
Dr. R.Thanga Prashath ${ }^{1}$ and Vinodkumar.K. ${ }^{2}$ \\ ${ }^{1}$ Assistant Professor, SrimadAndavan Arts \& Science College (Autonomous), \\ Trichirappalli, India. \\ ${ }^{2}$ Research Scholar, SrimadAndavan Arts \& Science College Autonomous), \\ Trichirappalli, India.
}

\begin{abstract}
The bilateral relationship between the two countries are one of the most important index of the strong relationship between two countries. It reflects the strong bond of commercial, industrial and foreign trade and subsequently results in the relationship in versatile manner in other sectors of cooperation including cultural, religious, political and economic. This paper depicts the bilateral relationship between India and Gulf region including the United Arab Emirates in the ancient period. The relationship between India and United Arab Emirates can't trace back exactly but all the literatures, relics and other evidences available showing that India and the countries of the GCC countries are having a strong bilateral trade, commercial and cultural relationship between these countries. The sources of data are mainly secondary in nature and the researcher collected data from the various secondary sources consists of text books, journals, news papers, websites and various published literatures. The relationship between these countries reached to a new level after the invention of Crude Oil in these region especially with United Arab Emirates after the union of seven emirates on 2nd December,1971 under the leadership of His Highness Sheikh Zayed Bin Sultan Al Nahyan. United Arab Emirates is one of the country where the largest Indian expatriate community is settled for their employment and business purposes and large number of Indian professional are deploying their skills and expertise for the development of both the countries. Now, the relationship between these countries are developed to a new strategic and commercial level and UAE became a new strategic partner in the middle east and at the international regime. All the policy decisions, bilateral agreements and strategies cultural, economic and commercial are showing that both the countries are treating each others are top priority strategic and vital partner in the Arab world resulting the enhanced investment of FDI in various sectors of these economy.
\end{abstract}


Keywords: UAE: United Arab Emirates, FDI: Foreign Direct Investment, LPG: Liberalisation, Privatisation and Globalisation, GDP: Gross Domestic Product, USD: United States Dollar, GCC: Gulf Cooperation Council.

\section{A. Importance of the Study}

This paper entitled "Bilateral Trade Relations between India and UAE- Historical Perspective" is an attempt to depict to the cooperation between the people between these two countries or regions. The largest population of the Indian expatriates are residing in this country and acting as the back bone of the development of the economy of UAE and also the back bone of their home land. Even though, the largest migration of Indian migrants to UAE reached after the invention of Crude Oil during 1960 's, there are lot of evidences showing that the Indian's are living in the Arab world 150 or 200 years ago. There are lot of references in the ancient history and civilization showing that India and Arab countries are having a strong cooperation in trade, commerce, cultural, religious and social. Contemporary, the relevance of these widespread relationship are relevant because both the countries are treating each other as the vital strategic partner in all round development and existence.

\section{B. Objectives of this paper}

1. To examine the history of economic and trade the association between India and United Arab Emirates (UAE).

\section{Methodology of Study}

The data used for preparing this paper are secondary in nature which are collected from the various published resources. The data derived for preparing this paper are from various relevant websites of Indian and UAE Embassy, Ministry of Commerce, journals and Publications of RBI. Director General of Foreign Trade, news papers , books etc.

\section{Review of Literature}

The review of literature consists of the existing relevant literatures or journals in the area of the bilateral relations between India and UAE. This section provides an insight into the existing or current level of knowledge in this area of research.

Heena Goel and Anjali Sharma, (2015) in their journal entitled "India's Merchandase Trade with UAE: Growth, Prospects and Future Potential" depicts India's merchandise trade with United Arab Emirates, its trends, growth, changes and composition of commodities between the periods 1997-1997 t0 2013-2014. In this journal the Authors approached this topic with some systematic quantitative techniques Real Growth Rate, Export and Import Intensity Index. The major findings 
of this paper is that the bilateral trade relations between India and UAE is developing in a systematic manner that result in the acceleration of the economic, commercial and strategic partnership between these countries.

Dr. Anup Barman, (2016) drawing the attention of the strong and concrete relationship between the two countries in all spheres after the union of the United Arab Emirates in 1971. He depicts the cooperation and relationship between these countries in all sectors of trade, commerce, economic, cultural and social aspects and also drawing attention to the various strategic investments in these countries.

Meena Singh ROy and Md. Muddassir Quamar, (2017) narrates Indo-UAE new strategic partnership in the light of the recent visit of the leaders of both countries expressing a strong bond of political commitment on both sides to expand their strategic ties and expansion in strategic areas like energy, security, defense Information Technology and Space.

Baldev Raj Nayar, (2006) in this paper, the author give a detailed account of the impact of globalisation to the India economy entitled " India's Globalisation: Evaluating the Economic Consequences". He describes the deep integration of the Indian economy with the global economy about the foreign trade and discussions of the macro economic indicators like GDP and the influence of the economic development, FDI and various social problems in the economy.

Nilanjana Kumar, (2010). The paper entitled "Effect of Economic Indicators on Export Performance of India: pre and post liberalisation period" narrates the impact of the export growth and the growth in various macro-economic indicators GDP, Per capita Income. Net National Income, Balance of Payment etc. during the period of 1986 to 2011.

\section{E. Findings and Discussions}

Much of the ancient history of the United Arab Emirates is still hidden beneath sand and dirt, awaiting to be discovered. The archaeological excavations that have taken place reveal evidence of people living in the region as far back as 6000 BC. Farming, fishing and copper work were part of their daily life.

The bilateral commercial and cultural relationship between India and UAE is timeimmemorial. Sharing the blue waters of Arabian sea, India and the Gulf region (including UAE) enjoy a deep and enduring relationship. Tracing the history of India's contacts with the Gulf region, UAE is having a greater role to play in many respects.

Countless artifacts from the Bronze Age onwards, retrieved from archaeological sites in the Indian subcontinent and West Asia and displayed in the modern-day museums throughout the region, bear testimony to the influence and interaction between the two populations for more than 5,000 years. Shards of pottery from Mesopotamia and the Indus Valley were among the objects uncovered during excavations of Hili tombs near Al Ain in United Arab Emirates. Another important site of discovery was 
TellAbraq, which is estimated to have been occupied for 2,000 years from about $2,300 \mathrm{BC}$. This site has revealed a prosperous settlement in an area that was once close to the sea and now lies on the border between Sharjah and Umm al-Qaiwain in the United Arab Emirates.1

1. Rajamony Venu.(2009). India and the UAE in Celebration of a Legendary friendship. Dubai, UAE. Indian Expressions Management Consultancy in association with Motivate publishing

Sumerian texts of ancient Mesopotamia or present-day Iraq repeatedly refer to three important centers with which they traded- Meluhha, Magan and Dilmun, Thesumerian identification of Magan was Oman and some parts of UAE, Dilmun, a trade distribution center for goods, is believed to the islands of Bahrain with some parts of Eastern province of Saudi Arabia and Meluhha was the Sumerian name for the Indus Vally Civilization.

Ancient records from Mesopotamia mention that Meluhha was a source of ivory and carnelian. Imported semi-precious stones such as agate and carnelian from the Indus Vally were highly sought after, along with precious metals such as gold and silver. Bead production in the Indus Valley was carried out on a mass scale and carnelian beads, along with carved figures and weights of Harappan type have been found at sites of Mesopotamia. The sheilhdoms that now from the UAE were an important link to the trade network for items such as ivory, along with the beads and precious and semi-precious metals that came from the Indus Valley. Many ivory combs have been discovered buried in the Bronze Age tombs at Tell Abraq and the discovery of some very distinctive types of seals used to mark the bundles of goods for trade were a significant indicator of how developed the trading activity had become.

The boat-builders and seafarers of the Gulf region were skilled navigators of the oceans. The Arabs used their knowledge to traverse the Mediterranean and even further afield trading in silk, spices and other precious goods like jade, gold, porcelain and herbs. Hippalus, the Greek navigator who lived in the first century BC is widely credited with the discovery, using it to find a direct route from the Red sea to India over the Indian Ocean by calculating accurately the trade winds that would take him to the ports along the Indian coast. This discovery led to a marked increase in commercial transactions with India. From Red Sea ports, Large ships crossed the Indian Ocean to the Kingdoms of Pandyas, Cholas and Cheras in present day Kerala and Tamil Nadu. The Roman Scholar Pliny the Eldor spoke of the ancient Indian port of Muziris and described Queen Hatshepsut of Egypt sent five ships to bring spices used in embalming and the manufacture of oils and perfumes. Huge stores of pepper, corns and coconuts have also been discovered from Berenike, a Roman settlement on Egypt's Red sea coast.

Traders in Ras Al Khaimah and Sharjah also set up flourishing businesses that exported pearls, horses and Basra dates to India. Pearls paid for many imported goods, much in the way that oil does today, and the pearl business allowed trade to thrive 
well into the 18th, 19th and 20th centuries.

Boat building was the vital element of all these marine activities and they used to use teak wood from India. The sambuq of Arabic origin continues to be constructed in boatbuilding yards on the west coast on India, with Beypore, south of modern-day Calicut being one of the most important centers. Beypore is a port of trade and a marine center which has been frequented by Arab, Chinese and European merchants for centuries. It is home to a 1,500 years tradition of ship-building especially the dhow and uru. These ships are also called 'Pathemari', 'Paikappal' or 'sailing ships' by the local population. Beypore has always been a major outlet for timber from kerala. Many people especially Arabs, preferred teak from the Kerala forests especially from Nilambur(the largest teak wood forests in the world) for building boats. Many Arabs buy uru's from Beypore.Several centuries ago, these Fat boats, known as 'pathemaris', carried spices and condiments across the Indian Ocean from India to the Arab countries; and have been silent witnesses to the flourishing maritime trade on the Malabar Coast.The Arabs are having a strong relationship with south Indian states like Kerala, Tamil Nadu, Andra Pradesh and Karnataka. The Arab merchants are used to stay in various places of Kerala especially Kozhikode for their commercial purposes and few are even married Indian women from such places.

The people of India and the Gulf have relations dating back over four millennia, when interactions centered on trade and cultural exchange. Since the beginning of the 1950's the UAE has developed good relations with India: social and commercial ties have flourished ever since. Tradesmen in both countries have played a significant role in building cultural, social and commercial bridges between their people. Such developments have placed India at the forefront of commercial and industrial exchange with the UAE, in addition to other non-petroleum industries. Despite increasing bilateral trade in energy and labour, India still has not viewed UAE through a strategic lens.

The most important evidence of the strong relations between India and UAE is that before the UAE Government's currency of Dirham in circulation in United Arab Emirates, the currency used in UAE was the 'Gulf Rupee'. Before the invention of Oil in Arab countries, there was no currency system and central banking was operating in the United Arab Emirates like other developed countries. UAE was under the alliance with British during those days and the trucial states used currency of the largest nation nearest to them was used as currency of these countries and up to until 1957, all the currencies prevailing in India were used in some Arab countries including the areas of UAE.

Until the middle of 20th century, the countries of the Persian Gulf and Arabian Peninsula was also used the Indian rupee as the official currency in these countries as well as in India. Those days, the Indian rupee was pegged to 1 British Pound $=13 \frac{1}{3}$ Indian rupees.

In 1957, in India printed special notes called 'External rupee' or Gulf rupees' for circulation in the Gulf region which are specially meant for preventing or curbing the widespread gold smuggling. The Gulf rupee notes were more or less similar to the 
Indian rupee which are printed and circulation in India, where as the colour were completely different and the Gulf rupee carried a special serial number prefix of ' $\mathrm{Z}$ ' over a number.

The currencies issued from India are of different denominations, 1 rupee issued by the Indian government and 5,10 and 100 rupee notes are issued by the Reserve Bank of India. The notes issued are in designs which are similar to the Indian notes where as printed in different colours. The currency notes of 1 rupee and 10 rupee were printed in red colour, where as the 5 rupee notes were printed in orange and 100 rupee notes in green colour.

In addition to UAE, other countries of GCC like Bahrain, Kuwait, Oman, Qatar except Saudi Arabia used Gulf Rupee as currency in their economy. During the period of 1957 to 1966, the Gulf Rupee was in circulation in these region and on 6th June, 1966, India devalued this Gulf Rupee against the India rupee. After the devaluation of the Gulf Rupee, the countries those used this currency adopted their own currencies, hence Kuawit had introduced Kuwait dinar and pegged to the Indian rupee, which was also pegged to the pound stirling. Followed by Bahrain introduced Bahraini dinar, Qatar and most of the other States (including UAE after 1971) adopted Qatar and Dubai Riyal which was equal to Gulf rupee prior to its devaluation. Abu Dhabi used the Bahraini dinar until 1973. Oman continued to use the Gulf rupee until 1970, with the government backing the currency at its old peg to the pound, when it adopted the Omani riyal.

\section{SamplesGulfRupee.1}

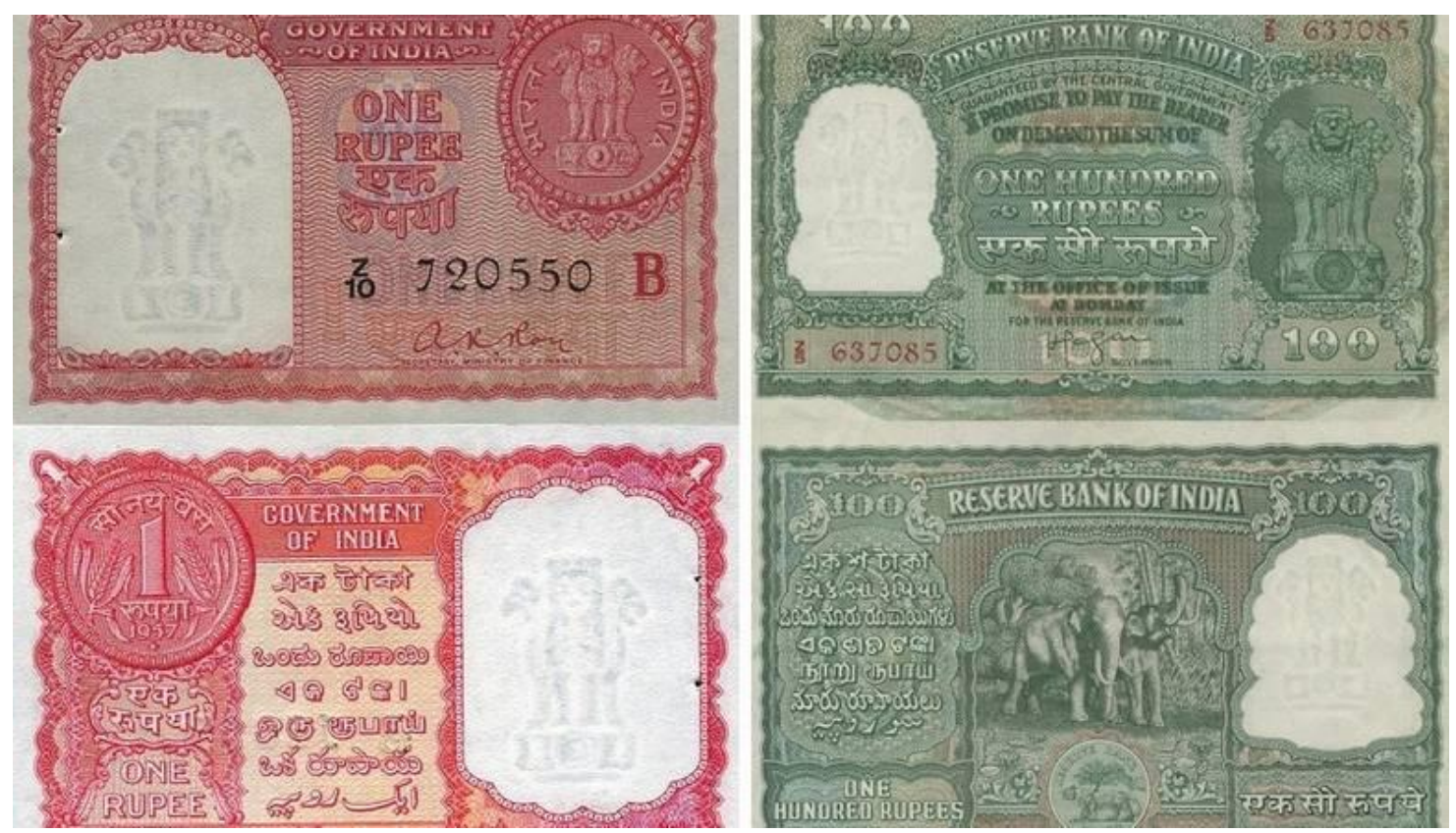

Figure No.1 


\section{F. Conclusion}

All the discussions in this paper depicting the relations between India and UAE is showing that there is a strong bond of relationship between these two countries centuries ago. All the evidences and relics recovered from various parts of undivided India, Persia and other Arab countries showing the diversified range of social, cultural, economic and trade relations between these regions at the early stages of development of civilization. The trade and commerce during the ancient periods was using simple logistics and transportation. The traditional relationshipalso results in the exchange and development of social, cultural, religious, linguistic and cross cultural relationship with the citizens of these countries evident in this study.

1.Rohma Sadaqat.(2017). Before the dirham UAE used the rupee. Retrieved January 27, 2017 from Khaleej Times.

\section{REFERENCES}

[1] Dr.Anup Barman. (2016). India-UAE Investment and Trade ConnectionPragmatism over the Hoopla and Hypes. Diplomacy and beyond: Special Report UAE-India, https://www .researchgatenet /publication/311705032. Retrieved June 12th, 2018, from https://www .researchgatenet.

[2] Heena Goel, Anjali Sharma. (2015). India's Merchadise Trade with UAE: Growth, Prospects and Future Potential. International Journal of Science Technology and Management, Vol.4,142-149.

[3] Nilanjana Kumar. (2012). Effect of Economic Indicators on Export Performance of India Pre and Postr Liberalisation Period. European Journal of Business and Management, Vol.4, 22-33.

[4] Meena Singh Roy, Md. Muddassar Quamar. (2016). India-UAE Relations: New Dimension to Strategic Partnership, Institute for Defense Studies and Analysis.

[5] Baldev Raj Nayar. (2006). India's Globalisation: Evaluating the economic consequences. East-West Center Washington publications.

[6] Rajamony Venu.(2009). India and the UAE in Celebration of a Legendary friendship. Dubai, UAE. Indian Expressions Management Consultancy in association with Motivate publishing

[7] Rohma Sadaqat.(2017). Before the dirham UAE used the rupee. Retrieved January 27, 2017 from Khaleej Times. 
